\title{
The role of digital marketing in improving SME's prod- uct competitiveness in The ASEAN Economic Community (AEC) (Case study in Indonesia)
}

\author{
Jono M Munandar ${ }^{1}$, Dadang Firmansyah ${ }^{2 *}$ \\ 1,2 Departement of Management Studies, Bogor Agriculture University, Bogor, Indonesia
}

\section{Keywords \\ Digital marketing \\ Improving SME's \\ ASEAN community}

Received: 12 June 2018

Accepted: 10 July 2018

Published: 2 August 2018

\begin{abstract}
Small Medium Enterprises (SME's); Usaha Kecil Menengah (UKM) has a huge contribution in indonesia and asean economic. There is $96 \%$ micro business in ASEAN and 99\% in Indonesia. Digital technology helps SME's move faster and more competitive in a national and international context. Technology and the Internet had a huge impact on economic growth in the world including Indonesia. The effective free market is the basic point of SMEs. Therefore, it needs the right strategy in increasing competitiveness to compete in AEC. Little Bandung is one of Bandung Goverment programs in increasing SME's to active in International business and contributes an economic growth nationally by becoming a part of the global value chain as a response to the AEC challenge. The purpose of this research is to identify the characteristics of SMEs in little Bandung. The research will analyze the impact of digital marketing on the competitiveness of SMEs little Bandung in AEC and the effectiveness factor of digital marketing in SMEs. The data collection process will be held in Indonesia. This research identifies three main variables that have the potential to influence Digital Marketing (DM) and Digital Leadership Capability (DLC) that is Digital Culture(DC), Digital Attitude (DA), Leadership Skill (LS). Furthermore, digital marketing and digital leadership capability are also tested whether they can influence competitiveness. The research is quantitative, which was collected by visiting SME's dan melalui google form. The data analysis method is partial least squares; structural equation modeling. The Findings depict that DA and LS have a significant effect on Digital Leadership Capability where an employee will have the capability if supported by the attitude and skills of the HR. Digital Culture and Digital Leadership Capability have a significant effect on Digital Marketing where every cultural dimension and capability of employees support in carrying out Digital Marketing. Digital Marketing has a significant effect on competitiveness where there is an influence between Digital Leadership Capability and Digital Marketing in running SME business performance.
\end{abstract}

(C) 2018 The Author(s). Published by TAF Publishing.

\section{INTRODUCTION}

The significant economiy growth in Indonesia relates to SME's. Based on Cooperative and SME's Ministry, SME's contributed about Rp.5.440 trillion into National Income, hired 114,14 millions employer, hold Rp.1.655,2 investment and created 57,8 business units. The number of SME's recorded up to 57.900 .000 units in 2016 and the number will increase about 59.000.000 units in 2017.

SME's has a huge contribution in Indonesian economic growth and ASEAN. Almost $96 \%$ of entreprises in ASEAN is micro business contributing about $33,1 \%$ to $57,6 \%$ for national income and hiring 46,8\% until 96,9\% employee. In this case, SME's is the most important element in increasing job opportunity and economic growth including national and regional (Ashardi, 2016; Nejad \& Poorsabzevari, 2016; Yoo, Lee, \& Lee, 2016).

Technology and Internet has a huge impact of economic growth in world including Indonesia. The business activities tend to condut via internet and indirect interaction. According to (Boonvut, 2017; Ginanjar, 2010; Putri, 2015), in-

\footnotetext{
*corresponding author: Dadang Firmansyah

†email: mr.dfirman@gmail.com
} 
ternet has an impact of transformational which increases new paradigma called DM in business. Not like traditional method, digital business reduces face to face activities because in now the business revolution is modern style which placing electronic or e-commerce in business activities. The digital business significantly influences in business activites in Indonesia. the data of Digital Landscape below, As shown in Table 1.

TABLE 1. Indonesia of of digital landscape, January 2018

\begin{tabular}{|c|c|c|c|c|}
\hline Total Population & Internet User & $\begin{array}{l}\text { Active Social } \\
\text { Media Users }\end{array}$ & $\begin{array}{l}\text { Unique Mobile } \\
\text { Useres }\end{array}$ & $\begin{array}{l}\text { Active Mobile } \\
\text { Social Users }\end{array}$ \\
\hline 265.4 Million & 132.7 Million & 130.0 Million & 177.9 Million & 120.0 Million \\
\hline Urbanisation & Penetration & Penetration & Penetration & Penetration \\
\hline $56 \%$ & $50 \%$ & $49 \%$ & $67 \%$ & $45 \%$ \\
\hline
\end{tabular}

(Source: Digital Di Indonesia (2018))

According to Tim Deloitte (2015) related economic modeling, penetration of digital SME's will increase 2\% Indonesia economic growth it becomes reason why many SME's had been apart of DM. The development of SME's move faster for income and job opportunity aspect which is more creative and competitive to face AEC challange.

Little Bandung is one of Bandung Goverment program in increasing SME's to active in Internatioal business and contributes an economic growth nationally with becoming a part of global value chain. This program relates to the vision of Bandung goverment for promoting the Bandung's product to domestic and international market as a response for AEC challange. Bandung created "goes online" program and had an honor from facebook as an online SME's partner.

The SME's influencer had many online business which supported by goverment. Therefore, the research will explore and analyze about the impact of digital marketing to increase SME's competitive with efective promotion. In addition, the research purposes to explain the impact of digital marketing in improving SME Product competitiveness in AEC. The research will conduct and take case in Indonesia.

\section{The Formulation of Problems}

The improvement of technology in digital marketing has been increase a significant business which supported by smartphone and broadband (Rudito \& Sinaga, 2017; Saputri, 2016). The efective of free trade ASEAN which held in 2015 is the basic segment of SME's. In that business the relation of each country was supported each other, such as free import cost and easy bureaucracy in increasing import comodity in each country of ASEAN. That is why it needs the right startegy in increasing competitiveness and human resources to face AEC.

Digital technology helps Indonesian SME's move faster and more competitive in national and even international. According to Deloitte Research which related to economic modelling in digital marketing, shows the relation between higher pendapatan, increasing job opportunity, inovation and export. Unfortunatelly, most of businessman did not consider how important digital marketing and the result is not optimal (Tim Deloitte, 2015; Selvina, 2016). Based on the statements of problems that have been described, the formulation of the research problems are :

1. What are the characteristics of SME's Little Bandung?

2. What is the impact of digital marketing in SME's competitiveness of Little Bandung?

3. What is the effectiveness factor of digital marketing in SME's?

\section{Research Objectives}

1. Identifying the characteristict of SME's Little Bandung.

2. Analyzing the relation of digital marketing to the competitiveness of SME's Little Bandung in AEC.

3. Analyzing the effectiveness factor of digital marketing in SME's.

\section{LITERATURE REVIEW}

According to Kotler and Keller. (2009), marketing is an activity of identifying the need to fill the need itself. Kottler has clasificated marketing models, those are concept needs, requestment, segmentation, targets and positioning, supply and brand, value and satisfied, marketing channels and supply chains, and competitive understanding. According to Chaffey and Chadwick (2016), digital marketing is an internet market, e-marketing and web market. Related to that definition, digital marketing is the achievement of marketing which uses technology and digital media.

According to George, Didier, and Andrew (2014), there are two dimension to get matriks $2 \times 2$ which shows 4 levels of digital mastery, those are : beginners, fashionistas, concervatives, and digital masters, As shown in Figure 1.

Based on the result, the most important factor in digitali- 
sation process is human, leadership, beliefes, mind set and positive response in improving digital technology, As shown in Figure 2.

According to Porter (1990) a country which has competitive advantage there is competitive company. A competi- tive country has been decided to be innovative and ability. There are 4 factors determination of competitive, those are factor conditions, demand conditions, related and supporting industries and also firm strategy, structure, and rivalry, As shown in Figure 3.

\begin{tabular}{|c|c|c|}
\hline 㚜 & $\begin{array}{l}\quad \text { Fashionistas } \\
\text { - } \quad \text { Many advanted digital feature } \\
\text { (Such, as social, mobile) in silos } \\
\text { - } \quad \text { No overarching vision } \\
\text { - Underdeveloped coordination } \\
\text { - } \quad \text { Digital culture may exist in silos }\end{array}$ & $\begin{array}{l}\quad \text { Digital Masters } \\
\text { - }\end{array}$ \\
\hline 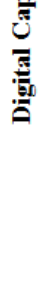 & $\begin{array}{l}\text { Beginners } \\
\text { - Management skeptical of the } \\
\text { busuness value of advanced digital } \\
\text { technologies } \\
\text { - May carry out experimentation } \\
\text { - Immature digital culture }\end{array}$ & $\begin{array}{l}\text { Concervatives } \\
\text { - } \quad \text { Overarching digital vision exists, but } \\
\text { may be underdeveloped } \\
\text { - Faw advanced digital features, } \\
\text { through traditional digital capabilities } \\
\text { may be mature } \\
\text { - } \quad \text { Strong digital governance across silos } \\
\text { - Taking active steps to build digital } \\
\text { skills and culture. }\end{array}$ \\
\hline
\end{tabular}

FIGURE 1. Levels of digital mastery George et al. (2014)

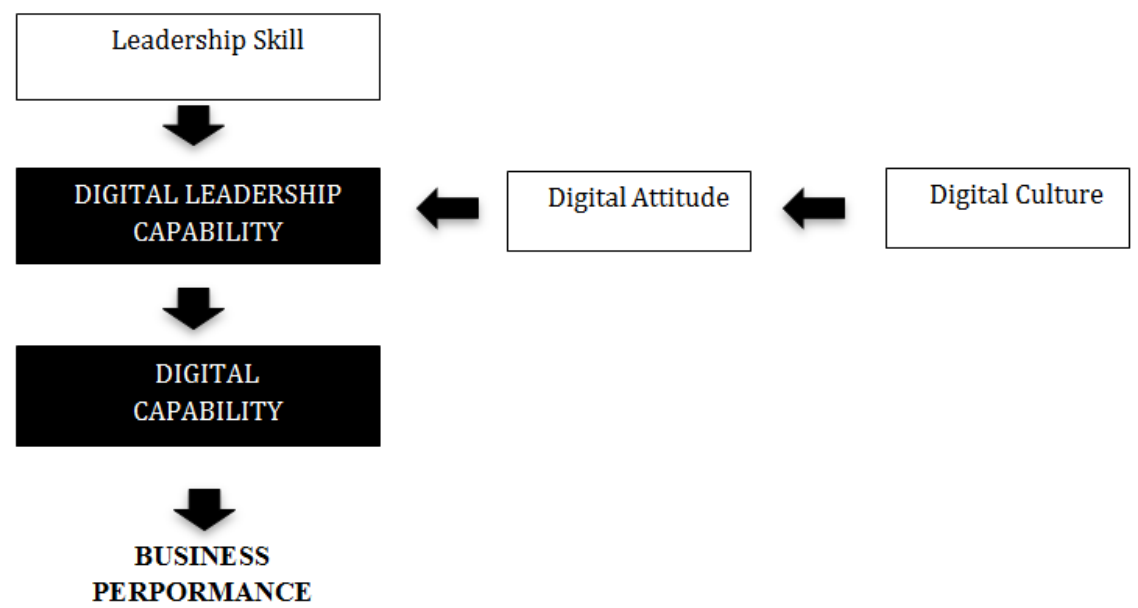

FIGURE 2. Digital mastery levers Rudito and Sinaga (2017)

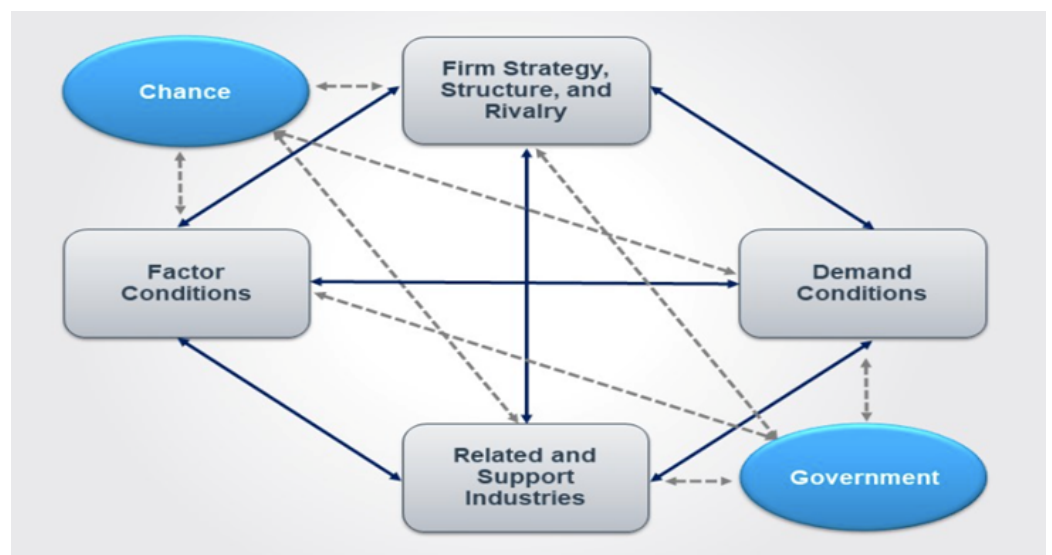

FIGURE 3. Diamond model porter (Source : Porter (1990)) 
According Porter (1990), there was a main competitive factor which called porter five forces model in analyzing competition analysis. The tool was created by Harvard Business School professor Michael Porter, to analyze an industry's attractiveness and likely profitability. Since its publication in 1979 , it has become one of the most popular and highly regarded business strategy tools. Porter recognized that organizations likely keep a close watch on their rivals, but he encouraged them to look beyond the actions of their competitors and examine what other factors could impact the business environment. He identified five forces that make up the competitive environment, and which can erode your profitability. These are

1. Competitive Rivalry. This looks at the number and strength of your competitors. How many rivals do you have? Who are they, and how does the quality of their products and services compare with yours? Where rivalry is intense, companies can attract customers with aggressive price cuts and high-impact marketing campaigns. Also, in markets with lots of rivals, your suppliers and buyers can go elsewhere if they feel that they're not getting a good deal from you. On the other hand, where competitive rivalry is minimal, and no one else is doing what you do, then you'll likely have tremendous strength and healthy profits.

2. Supplier Power. This is determined by how easy it is for your suppliers to increase their prices. How many potential suppliers do you have? How unique is the product or service that they provide, and how expensive would it be to switch from one supplier to another?

The more you have to choose from, the easier it will be to switch to a cheaper alternative. But the fewer suppliers there are, and the more you need their help, the stronger their position and their ability to charge you more. That can impact your profit.

3. Buyer Power. Here, you ask yourself how easy it is for buyers to drive your prices down. How many buyers are there, and how big are their orders? How much would it cost them to switch from your products and services to those of a rival? Are your buyers strong enough to dictate terms to you? When you deal with only a few savvy customers, they have more power, but your power increases if you have many customers.

4. Threat of Substitution. This refers to the likelihood of your customers finding a different way of doing what you do. For example, if you supply a unique software product that automates an important process, people may substitute it by doing the process manually or by outsourcing it. A substitution that is easy and cheap to make can weaken your position and threaten your profitability.
5. Threat of New Entry. Your position can be affected by people's ability to enter your market. So, think about how easily this could be done. How easy is it to get a foothold in your industry or market? How much would it cost, and how tightly is your sector regulated?

If it takes little money and effort to enter your market and compete effectively, or if you have little protection for your key technologies, then rivals can quickly enter your market and weaken your position. If you have strong and durable barriers to entry, then you can preserve a favorable position and take fair advantage of it.

\section{Reference of Study}

According to Tiago and Veríssimo (2014) digital marketing and social media: why bother?, pemasar had been taken control social media as a source of digital relation: (1) digital company or interactive, keeping digital market. (2) adopting several factors of social media interaction in improving digital marketing. These domain was related to be a part of improvement.

According to Syahmardi and Ade (2016), the advantages of social commerce with high competitive of umkm in jambi province. The research has been analyzed that s-commerce has no impact in UMKM business becasue there was not significant contribution in improving SME's business in Jambi. According to Wardhana (2016), digital marketing strategies and implication of SME's competitive in Indonesia. Related to that research, the implication of digital marketing had its own advantages with $78 \%$ selling product and $22 \%$ refund. That was caused there is no identifying research data such as capital capability, resource supply and professional managerial.

\section{RESEARCH METHODOLOGY Conceptual Framework}

There was several subtemas which hold SME's characters, SME's competitive, and digital marketing capability, As shown in Figure 4.

\section{Location and Schedule of Research}

The research location has been taken with purposive in improving goes online UKM program which colletcting online questionnaire and visiting SME Little Bandung on Mei - July 2018, Collecting data process will held in Bandung.

\section{Collecting Method}

The population of this research was SMEs Little Bandung. According to Industry and Trade Department in Bandung or "Dinas Perindurstrian and Perdagangan Bandung", there was 166 SME's, and data collecting taken around a two 
month. Data collection was done by census method for SMEs who are members of the Little Bandung. Respondent data collected during the two months were 105 respon- dents from 128 in the fashion category with a total of 166 SMEs in the Fashion, craft and culinary categories and other categories, namely makeup and soap.



FIGURE 4. Research framework

\section{Processing Data Analysis Methods}

The method of this research is quantitative descriptive analysis which focus on respondents characteristic, dominan in- tention and factor of SME's digital marketing. The quantitative data will process with Partial Least Squares (PLS) Structural Equation Model (SEM). as shown in Figure 5.

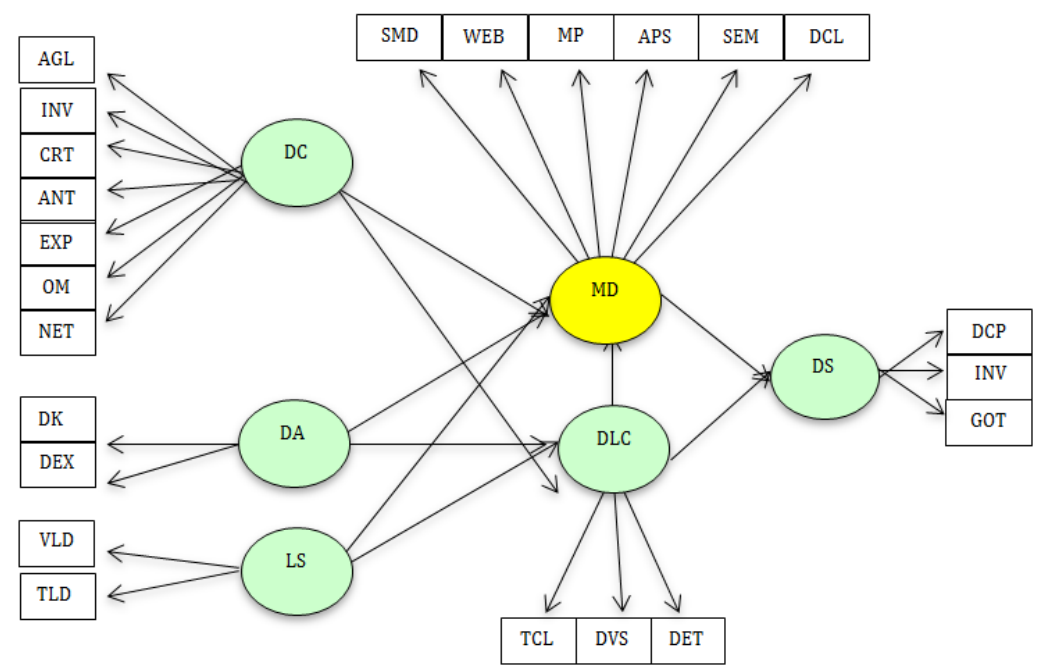

FIGURE 5. Analysis methods PLS-SEM 
TABLE 2. Indicator relations with latent variables

\begin{tabular}{|c|c|c|}
\hline Indicator & Information & Description \\
\hline \multicolumn{3}{|c|}{ Digital Culture } \\
\hline $\mathrm{AGL}_{1}$ & Agility & $\begin{array}{l}\text { The capacity to constantly transform and } \\
\text { experiment }\end{array}$ \\
\hline $\mathrm{INV}_{2}$ & Innovation & Innovationconcerns \\
\hline $\mathrm{CRT}_{3}$ & Creativity & Ability to be creative \\
\hline $\mathrm{ATB}_{4}$ & Anticipator & $\begin{array}{l}\text { Ability to anticipate and act fast in urgent } \\
\text { circumstances }\end{array}$ \\
\hline $\mathrm{EXP}_{5}$ & Experiment & $\begin{array}{l}\text { The Willingness to seek and try something } \\
\text { new }\end{array}$ \\
\hline $\mathrm{OMD}_{6}$ & Open Mindset & $\begin{array}{l}\text { Availability of information and freedom to } \\
\text { communicate }\end{array}$ \\
\hline $\mathrm{NET}_{7}$ & Networking & $\begin{array}{l}\text { The development of networks of relation } \\
\text { between all of the company's stakeholder }\end{array}$ \\
\hline \multicolumn{3}{|c|}{ Digital Attitude } \\
\hline $\mathrm{DKN}_{1}$ & Digital Knowledge & $\begin{array}{l}\text { General knowledge about digital applica- } \\
\text { tion }\end{array}$ \\
\hline $\mathrm{DEX}_{2}$ & Digital experience & $\begin{array}{l}\text { Experience on using business application } \\
\text { that is relevant with the level of leader- } \\
\text { ship. }\end{array}$ \\
\hline \multicolumn{3}{|c|}{ Leadership Skill } \\
\hline $\mathrm{VLD}_{1}$ & Visionary Leadership & $\begin{array}{l}\text { Skill to creat vision, mission, objectivesa } \\
\text { and goals }\end{array}$ \\
\hline $\mathrm{TLD}_{2}$ & Transformational Leadership & Skill to manage change \\
\hline \multicolumn{3}{|c|}{ Digital Leadership Capabiliti } \\
\hline $\mathrm{TCL}_{1}$ & Technology Leadership & Knowledge based on digital application \\
\hline $\mathrm{DVS}_{2}$ & Digital Visioning & Skill needed to create digital vition \\
\hline $\mathrm{DEC}_{3}$ & Digital Execution & Skill to create digital business \\
\hline \multicolumn{3}{|c|}{ Digital Marketing } \\
\hline $\mathrm{SMD}_{1}$ & Social Media & Facebook, instagram, \\
\hline $\mathrm{WEB}_{2}$ & Website & Website Product \\
\hline $\mathrm{MP}_{3}$ & Market Place & e-commerce \\
\hline $\mathrm{APS}_{4}$ & Mobile Applications & Mobile application product \\
\hline $\mathrm{SEM}_{5}$ & Search & Engine Marketing \\
\hline $\mathrm{DCL}_{6}$ & Digital Colaborations & Whatsapp, Line, Youtube, Email \\
\hline \multicolumn{3}{|c|}{ Competitiveness } \\
\hline $\mathrm{DCP}_{1}$ & Dinamyc Capabilities & Dinamyc Capabilities of team \\
\hline $\mathrm{INV}_{2}$ & Innovation & Innovation product \\
\hline $\mathrm{GOT}_{3}$ & Global Orientation & Global Orientation business unit/SMEs \\
\hline
\end{tabular}

\section{Hypothesis of the Research}

H1a : Digital Culture positively influences toward Digital Marketing

H1b: Digital Culture positively influences toward Digital Leadership Capability

H2a : Digital Attitude positively influences toward Digital Marketing

H2b : Digital Attitude berpengaruh positif terhadap Digital
Leadership Capability

H3a: Leadership Skill positively influences toward Digital Marketing

H3b: Leadership Skill positively influences toward Digital Leadership Capability

H4a: Digital Leadership Capability positively influences toward Digital Marketing 
H4b: Digital Leadership Capability positively influences toward Digital Leadership Capability

H5 : Digital Marketing positively influences toward SME's Competitiveness

\section{RESULTS AND DISCUSSIONS}

The city of Bandung was located at positions $107^{\circ} 36$ 'East Longitude and $6^{\circ} 55^{\prime}$ South Latitude. The area of Bandung City is 16,729.65 hectares. The city of Bandung was located at an altitude of 791 meters Above Sea Level (ASL). The highest point is in the North with an altitude of 1,050 m asl and the lowest point is in the South with an altitude of 675 $\mathrm{m}$ above sea level. The city of Bandung is one of the cities in West Java Province that has economic potential. The potention of economic conditions can be seen from the increasing number of creative industries in the city of Bandung. Creative industries in the city of Bandung are dominated by Micro, SMEs. SMEs had an important role in the economy. This was indicated by the ability of SMEs to mobilize local and national economic activities and provide employment. According to Humas Kota Bundung (2018) SMEs in the city of Bandung have won the Natamukti Nindya award as the city with the best SMEs development in Indonesia based on the Indonesia Council for Small Business (ICSB) and the Ministry of Cooperatives and SMEs. The award was received by the Mayor of Bandung Ridwan Kamil in 2016. Bandung received an award for being able to create a good economic climate. In addition, Bandung local products managed to penetrate the international market. Rupiah turnover generated from small-scale industries in online shopping, there are around Rp. 20 million per year transactions from 300,000 SME-level businesses in Bandung. SMEs had a very important role for economic growth. In its development, SMEs contributed a lot to the national economy, including giving a role in absorbing a lot of workers so that it helped the government in solving unemployment problems, expanding employment, increasing people's income and contributing foreign exchange to state revenues through exports.

In this research the authors chose SMEs incorporated in Little Bandung because Bandung City SMEs are an example in increasing SMEs stretching for other cities / regencies in Indonesia. Little Bandung is Ridwan Kamil's program as Mayor which was launched in 2016 through the Bandung City Office of Industry and Trade. In Little Bandung there are 170 SMEs joined since 2016 divided into several categories, namely fashion, craft, culinary and others, but the respondents in this study are specifically in the fashion category with 105 SMEs.

\section{Characteristics of Respondents}

Respondents in this study amounted 105 SMEs, all of whom were in the city of Bandung which was incorporated in Little Bandung with the following characteristics.

TABLE 3. Characteristics of respondents

\begin{tabular}{llll}
\hline \hline Characteristics & & Total & Percentage (\%) \\
\hline Business fields & Fashion & 105 & $100 \%$ \\
Gender & Male & 59 & 56 \\
& Female & 46 & 44 \\
Age & Total & 105 & 100 \\
& $16-25$ th & 8 & 7.6 \\
& $26-35$ th & 72 & 68.5 \\
Education & $36-45$ th & 15 & 14.3 \\
& $46-55$ th & 9 & 8.6 \\
& $56-65$ th & 1 & 1 \\
& Total & 105 & 100 \\
& Senior High School & 50 & 47.6 \\
& Diploma & 17 & 16.2 \\
& Bachelor & 34 & 32.4 \\
& Magister & 3 & 2.9 \\
& Doktor & 1 & 1 \\
& Total & 105 & 100 \\
\hline \hline
\end{tabular}

(Source: Processed Data on Primary Data, 2018) 
Table 3. Continue..

\begin{tabular}{llll}
\hline Characteristics & & Total & Percentage (\%) \\
\hline Long running business & 1 th & 0 & 0 \\
& 2 th & 22 & 21 \\
3 th & 30 & 28.6 \\
4 th & 11 & 10.5 \\
5 th & 16 & 15.2 \\
$6-10$ th & 22 & 21 \\
$11-15$ th & 4 & 3.8 \\
Employees & Total & 105 & 100 \\
& $1-5$ org & 69 & 65.7 \\
& $6-10$ org & 19 & 18.1 \\
& $11-15$ org & 14 & 13.3 \\
$16-50$ org & 2 & 1.9 \\
& $51-100$ org & 1 & 1 \\
& $101-200$ org & 0 & 0 \\
& Total org & 0 & 0 \\
& Ton & 105 & 100 \\
\hline \hline
\end{tabular}

(Source: Processed Data on Primary Data, 2018)

The Relationship of the Role of Digital Marketing to the Competitiveness of Small and Medium Enterprises (SMEs) Products

In this research, variable testing had been using SEM PLS analysis which aims to see the orientation of explosiveary predictions with the approach of two sub models. Measurement model (outer model) and structural (inner model). According to (Ghozali, 2008), the outer model - reflective evaluation is carried out based on five criteria, namely convergent validity checks, discriminat validity and composite reliability, crossloading, cronch alpha. Evaluation of this model was analyzed using SMART PLS 3.0 software, Evaluation of the outer model was carried out in two stages, namely the initial model and the model specification.
In the first step by putting the value of the loading factor for each indicator. The isssu of indicators contained in the construct had been launched based on the standardization of the loading factor value $>0.7$. The loading factor value $>0.7$ indicates valid with the construct. This study uses a standard loading factor of 0.7 , if the construct indicator value is $<0.7$, it must be removed from the model. After evaluating the construct variable indicator through the standardized loading factor value, this model is re-estimated, namely through the PLS Algorithm test. The test results will show some explanations in the form of loading factor value, average variance extracted, cross loading, composite realibility and cronch alpha. Criteria and standardization of evaluation of the outer models are presented in Table 4.

TABLE 4. Results of model suitability criteria

\begin{tabular}{|c|c|c|c|c|}
\hline Kriteria & & Standar & Hasil & Keterangan \\
\hline Loading Factor & & $<0.7$ & $\begin{array}{l}\text { Indicator ANT, CRT, EXP, } \\
\text { INV, NET, OM, DEX, DK, } \\
\text { TDL, VLD, DET, DVS, TCL, } \\
\text { SEM, SMD, WEB, GOT, IP }\end{array}$ & Valid \\
\hline $\begin{array}{l}\text { Average Variance } \\
\text { tracted (AVE) }\end{array}$ & Ex- & $>0.5$ & $\begin{array}{l}\text { DA : } 0.722 \text { DS : } 0.806 \text { DC } \\
: 0.636 \text { LS : } 0.766 \text { DLC : } \\
0.647 \text { MD : } 0.685\end{array}$ & Valid \\
\hline Composite Reability & & $>0.6$ & $\begin{array}{l}\text { DA : } 0.838 \text { DS : } 0.893 \text { DC } \\
: 0.913 \text { LS : } 0.868 \text { DLC : } \\
0.846 \text { MD : } 0.867\end{array}$ & Realible \\
\hline
\end{tabular}

(Source : Processed Data on Primary Data, 2018) 
Table 4. Continue...

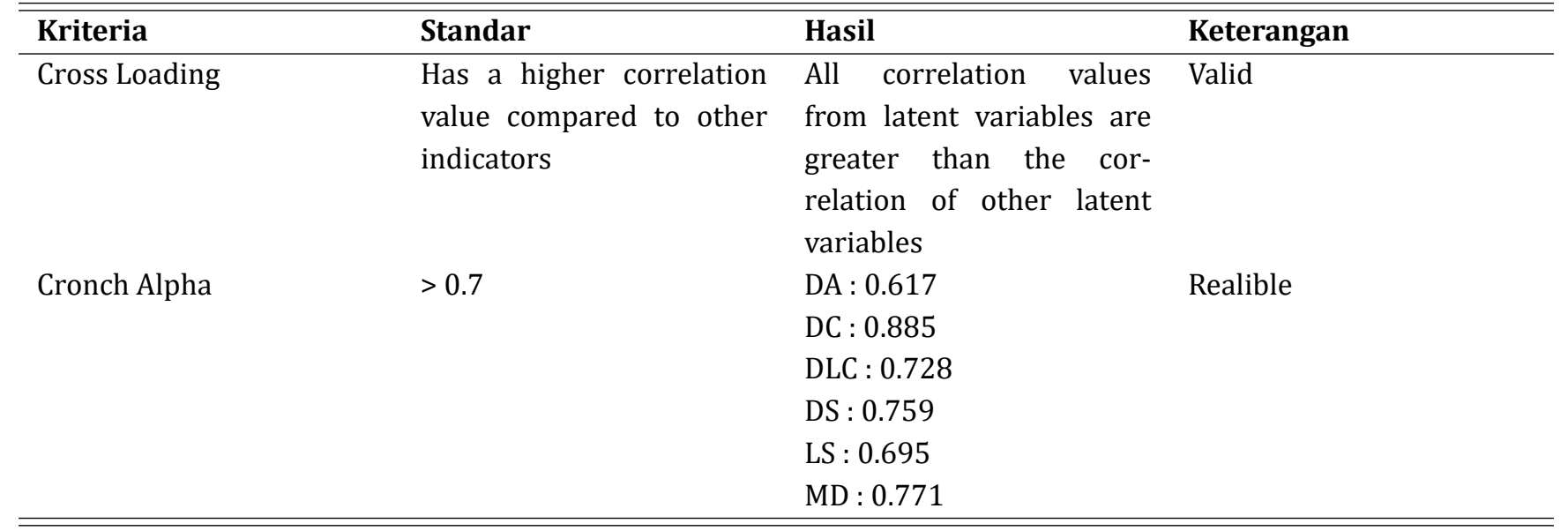

(Source : Processed Data on Primary Data, 2018)

Construct validity was assessed based on Average Variance Extracted (AVE). In this research the AVE value of each construct is above 0.5 Therefore there is no problem of converging validity in the model being tested. All models are valid. The reliability of the construct is assessed based on Composite Reability to measure internal consistency and the value must be above 0.6 . based on table 4 the overall Composite reability measurement results are above 0.6 or real. This meant that the data has been consistent and able to explain the model. Besides the results of the calculation of all variables that the value of Cronbach's Alpha is $>0.7$, the value of Composite Reliability > 0.6 and the value of AVE is $>0.5$ means that all variables are reliable.

\section{Initial Model Evaluation Results}

The loading factor value is an individual reflective measure that has a standard of 0.7 (Ghozali, 2008). Based on the results of the study, the loading factor below 0.7 must be removed from the model. After the release of indicators that do not meet the standards, namely 3Yr, AGL, APS, DCL, DCV, MP, the model meets the first requirement. So that the path diagram of the final recipient model can be seen in Figure 7.

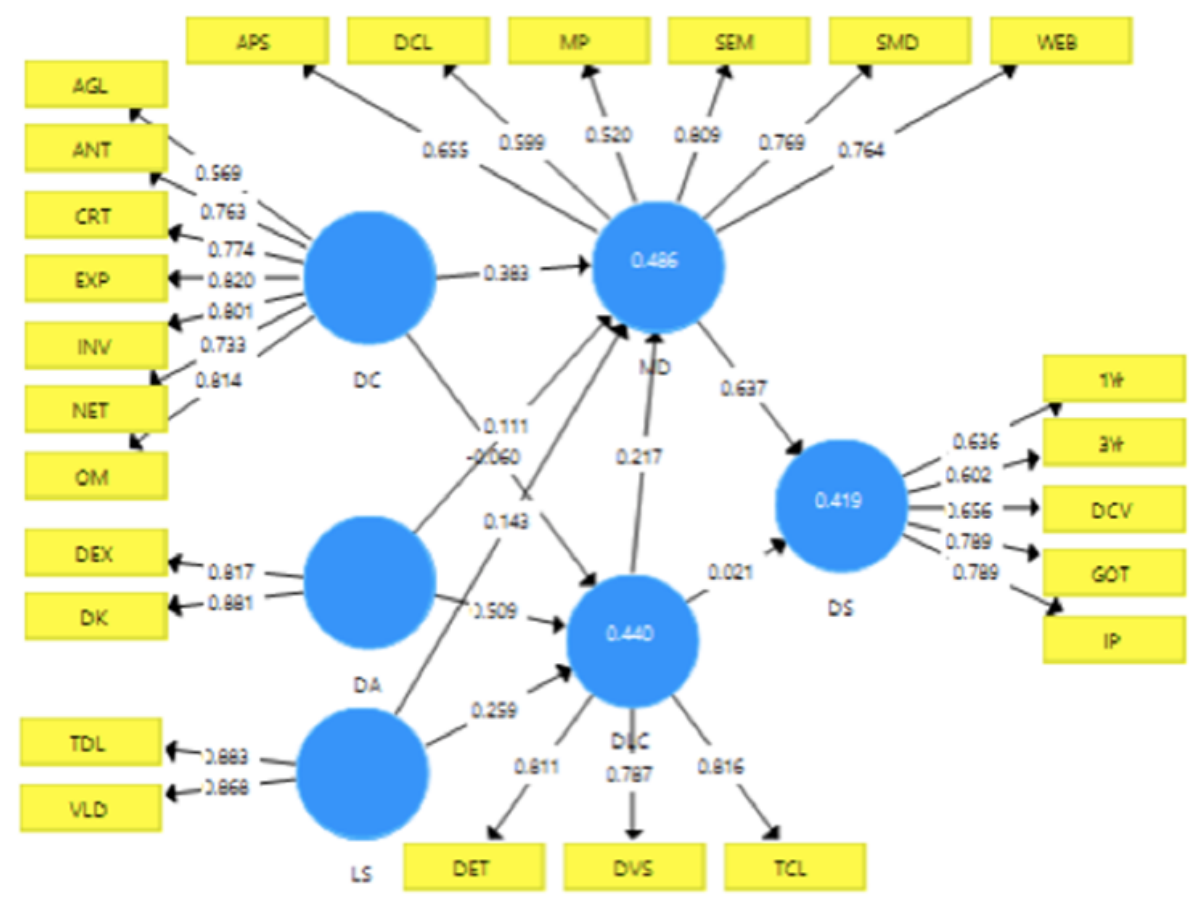

FIGURE 6. Path diagram with initial loading factor 


\section{Inner Model Evaluation Results}

The testing of this hypothesis aims to see the significance of the influence between variables on competitiveness at a significance level of $\alpha=0.5 \%(0.05)$. Based on the results of the inner model test (Structural Model) through Smart PLS 3.0 results obtained as in Figure 7.

Following the results of the significance test obtained from Table 5. the path coefficients are as follows.

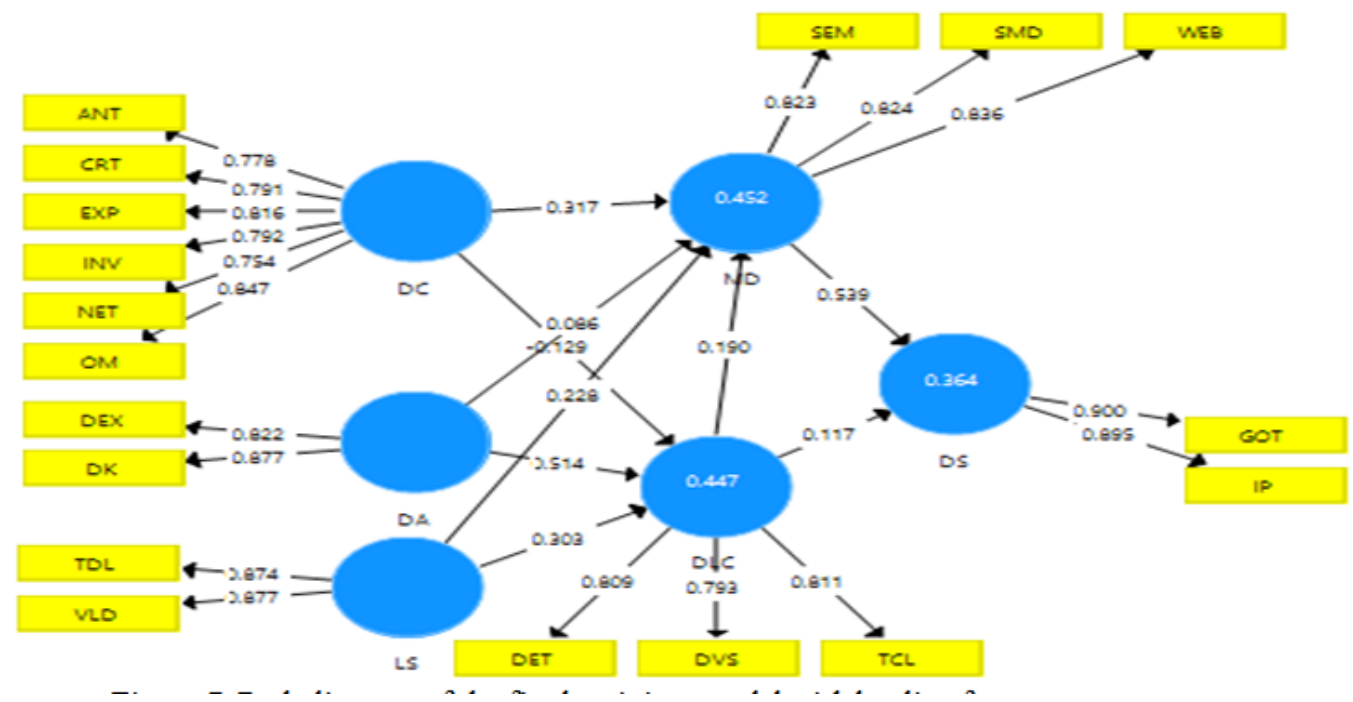

FIGURE 7. Path diagram of the final recipient model with loading factor

TABLE 5. Hypothesis Testing

\begin{tabular}{llllll}
\hline \hline Variables & Coeffisients & Standard $\boldsymbol{D}$ & $\boldsymbol{T}$ Statistics & $\boldsymbol{p}$ Values & Information \\
\hline DC -> MD & 0.317 & 0.102 & 3.112 & 0.002 & Significant \\
DC -> DLC & -0.129 & 0.112 & 1.147 & 0.252 & Not Significant \\
DA -> DLC & 0.514 & 0.094 & 5.447 & 0.000 & Significant \\
DA -> MD & 0.086 & 0.113 & 0.762 & 0.447 & Not Significant \\
LS -> DLC & 0.303 & 0.116 & 2.610 & 0.009 & Significant \\
LS -> MD & 0.228 & 0.121 & 1.890 & 0.059 & Not Significant \\
DLC -> MD & 0.190 & 0.097 & 1.964 & 0.050 & Significant \\
DLC -> DS & 0.117 & 0.084 & 1.389 & 0.166 & Not Significant \\
MD -> DS & 0.539 & 0.080 & 6.779 & 0.000 & Significant \\
\hline \hline
\end{tabular}

Description: $p$-value $<0.05=$ significant

Based on the results of testing the hypothesis there were:

1. Digital Culture has a significant effect on Digital Marketing

2. Digital Attitude has a significant effect on Digital Leadership Capability

3. Leadership Skill has a significant effect on Digital Leadership Capability

4. Digital Leadership Capability has a significant effect on Digital Marketing

5. Digital Marketing has a significant effect on competitiveness

Based on Table 5 testing the effect of DC to MD produces a parameter coefficient of 0.317 and a statistical value of $t$ is 3.112 with a significance level $(p$-value $)=0.002(<0.05)$. These results indicated that the influence of DC on MD is positive and significant, so $\mathrm{H} 1 \mathrm{a}$ is accepted, which means that Digital Culture has an effect on Digital Marketing while the Digital Leadership Capability has no effect which meant that $\mathrm{H} 1 \mathrm{~b}$ is rejected.

Testing the effect between DA and DLC results in a parameter coefficient of 0.514 and a statistical value of $t$ of 5.447 with a significant level ( $p$-value) $=0.000(<0.05)$. These results indicated that the influence of DA on DLC is positive and significant, then $\mathrm{H} 2 \mathrm{~b}$ is accepted which means that Dig- 
ital Attitude has an effect on Digital Leadership Capability while on Digital Marketing has no effect, H2a is rejected. Testing the effect of LS on DLC results in a parameter coefficient of 0.303 and a statistical value of $t$ of 2.610 with a level of significance $(p$-value $)=0.009(>0.05)$. These results indicate that the effect of LS on DLC is positive and significant, so H3b was accepted, which meant that Leadership Skill has an effect on Digital Leadership Capability, while for Digital Marketing has no effect, H3a was rejected.

Testing of DLC to MD produces a parameter coefficient of 0.190 and a statistical value of $t$ is 1.964 with a significance level $(p$-value $)=0.050(>0.05)$. These results indicate that the influence between DLC on MD is positive and significant, then $\mathrm{H} 4 \mathrm{a}$ is accepted which means that Digital Leadership Skill has an effect on Digital Marketing while the Competitiveness has no effect, $\mathrm{H} 4 \mathrm{~b}$ is rejected.

Testing the effect of MD on DS results in a parameter coefficient of 0.539 and a statistical value of $t$ of 6.779 with a significance level $(p$-value $)=0.000(>0.05)$. These results indicate that the effect of MD on DS is positive and significant, then H5 was accepted, which meant that Digital Marketing influences competitiveness.

The variables that did not significantly influence SMEs in Little Bandung were Digital Culture on Digital Leadership Capability, Digital Attitude towards Digital Marketing, Leadership Skill for Digital Marketing and Digital Leadership Capability for Digital Marketing and Digital Leadership Capability for Competitiveness. Based on the analysis that causes the DLC variable does not have a significant effect on competitiveness, SMEs are more adaptable or transformational directly to the use of digital marketing, namely the use of social media than they have to learn to create websites to improve digital capability. this is consistent with the research based on Rudito and Sinaga (2017) that technological readiness, owner innovation, owner's IT capabilities and owner's IT experience are the determining factors that influence Indonesian SMEs in adopting e-commerce. Basically this research is in line that digital attitudes will affect the digital capability of SMEs, especially in this study, in adopting ecomerse.

\section{Digital Marketing Effectiveness Factors in Small and Medium Enterprises (SMEs) Little Bandung}

Based on the findings of the Digital Mastery model that the most important factor in digitalization is human, both leadership capacity, values believed, patterns of thinking and positive attitudes in response to advances in digital technology. Based on hypothesis 1 that Digital Culture has a significant effect on digital marketing (1a) and Digital Lead- ership Capability (1b), the results of the analysis show that Digital Culture only has a significant effect on Digital Marketing, meaning that $\mathrm{H} 1 \mathrm{a}$ is accepted. This is in line with the field that the majority of SMEs familiarize themselves with digital culture directly with the practice from through workshops to improve their digital leadership capabilities first. Based on (Rudito \& Sinaga, 2017) Organizational Culture is a collection of beliefs, behaviors and work practices developed by employees, if carried out within the organization it will become an organizational identity. While Digital Culture is a conducive organizational culture that supports the adoption and development of digital technology to produce business performance and sustainable success. This was achieved because most of the characteristics ranging from 16-35 years old around $80 \%$ of the total respondents and education levels of $50 \%$ of high school graduates and $50 \%$ of graduates of Bachelor, Masters and Doctorate because digital culture requires human resources who had the character of agility, dynamic, open mind, innovation and adaptability to new things.

The result of hypothesis H2b was accepted and H2a was rejected, namely Digital Attitude has a significant effect on Digital Leadership Capability and has no effect on digital Marketing. A digital leader basically must have a positive attitude towards digital technology. Digital Attitude here is employees' perception of digital technology used by companies in carrying out their work. In the digital era according to (Rudito \& Sinaga, 2017) In general there are three attitudes of employees in seeing the advancement of digital technology, namely 1 . Those who turn a blind eye or do not want to know that technological progress cannot be applied in their companies. 2. Those who try to understand and go with the flow in changes in technological progress and 3. Those who are young (generations $\mathrm{X}$ and Y) are able to follow digitalization naturally and can use it intelligently. From the questionnaire that the writer asked the respondent related to Digital Attitude variables are two key elements based on Rudito and Sinaga (2017) 1. Digital knowledge and digital experience, of course, this digital attitude will be obtained by employees through workshops or their work experience so that Attitude Digital is very influential shape the capabilities of employees.

H3a hypothesis was accepted and H3b was rejected, namely Leadership Skill has an effect on Digital Leadership Capability and has no effect on Digital Marketing. This can be concluded because Leadership that must be developed to become a capable digital leader must have visionary leadership skills and transformational leadership, in other words 
able to manage and control digital transformations that continue to experience disruption.

The H4a hypothesis was accepted and $\mathrm{H} 4 \mathrm{~b}$ was rejected namely Digital Leadership Capability had a significant effect on Digital Marketing and had no effect on Competitiveness and Digital Marketing had a significant effect on competitiveness, then H5 was accepted. Digital Leadership Capability was formed by variables such as Digital Culture and Digital Attitude and Leadership Skills so that Employees had digital knowledge and capabilities so that employees can carry out their work, one of them is Digital Marketing. And through Digital Marketing promotion a company can runs promotions efficiently and unlimited georaphically because through online promotion all consumers can access it. Finally, through Digital Marketing, it can increase competitiveness by utilizing technological advancements, namely by increasing the human resources strategy in having digital capabilities and digital knowledge which was used as a digital culture and digital attitude in carrying out business performance in the company.

\section{Managerial Implications}

UKM has a contribution to the economic progress of this country and ASEAN. This is evident that SMEs can absorb a considerable amount of labor, capable of contributing to a considerable national GDP. Based on the results of this study explained the characteristics of SME entrepreneurs in Indonesia. The majority of business people are dominated by productive age and educational background of Diploma and Bachelor, so that SMEs are expected to be able to quickly adapt in the digital era at this time in order to capture opportunities for the progress of their business.

In the results of the research Digital Attitude and Leadership Skill variables have a significant effect on Digital Leardership Capability, which means that individual abilities become a benchmark in improving capability in running a business, which means more SMEs have workforce having skills and digital attitudes, capability or professional digital opportunities will be able to quickly materialize which ultimately can compete in digital media because it has digital competence. This is also supported by the results of research that digital culture has an effect on digital marketing, which means that when the personal workforce of SMEs is accustomed to running a digital work culture, it will influence digital marketing.

\section{CONCLUSION}

Based on the results of the research that has been obtained, it can be concluded as follows :

1. Digital Attitude and Leadership Skills have a significant effect on Digital Leadership Capability where an employee will have Capability if supported by the attitude and skills of the HR.

2. Digital Culture and Digital Leadership Capability has a significant effect on Digital Marketing where every cultural dimension and capability of employees support in carrying out Digital Marketing.

3. Digital Marketing has a significant effect on competitiveness where there is an influence between Digital Leadership Capability and Digital Marketing in running SME business performance.

\section{SUGGESTION}

Based on the conclusion of the study, the following suggestions were submitted: 1 . For the Bandung Litte UKM

a) The results of this study were expected to be used as consideration for management and owners of SMEs, that in order to improve competitiveness, it requires the right digital marketing strategy, selective social media selection, and making social media the spearhead of marketing communication.

b) To improve the Bandung City digital marketing capabilities of SMEs through the use of social media, web and marketplace at a better quality level, it was expected that SME management will provide soft skills workshops/training to SME social media administrators in the form of; (1) writing skills in marketing communication content, (2) skills in using various social media strategy applications, (3) and Social Customer Relationship Management (SCRM) skills.

2. For academics

a) The study of the influence of digital marketing on the competitiveness of SMEs can be further developed for further researchers, by trying other indicators that can reflect the dimensions of digital marketing and competitiveness.

b) The need for an in-depth study related to the results of the research Digital marketing influence on the competitiveness of SMEs in Indonesia and ASEAN, given the many diversity of factors that can influence the contribution of digital marketing to the competitiveness of SMEs apart from the factors revealed in this study.

\section{REFERENCES}

Ashardi. (2016). Geliat UMKM di era MEA: Media publikasi direktorat jendral kerjasama ASEAN kementrian luar negeri RI. Retrieved from https://bit. ly/2AJoqHg (accessed on 7 February, 2018) 
Boonvut, S. (2017). The quality financial statements of Small and Medium Enterprises Business (SME's) in view of the tax auditor. International Journal of Business and Economic Affairs, 2(6), 335-340. doi:https://doi.org/10.24088/ ijbea-2017-26002

Chaffey, D., \& Chadwick, F. E. (2016). Digital marketing. Edinburgh, UK: Pearson Education Limited Edinburgh Gate.

Digital Di Indonesia. (2018). Global digital report 2018: World's internet users pass the 4 billion mark. Retrieved from https://bit.1y/2Fx8urq (accessed 1 February, 2018)

George, W., Didier, B., \& Andrew, M. (2014). Leading digital: Turning technology into business transformation. Boston, MA: Harvard Business Review Press.

Ghozali, I. (2008). Structural equetion modeling metode alternatif dengan partial least square (Unpublsihed master's thesis). Universitas Diponegoro, Semarang, Indonesia.

Ginanjar, S. (2010). Analsis pengaruh inovasi produk melalui kinerja pemasaran untuk mencapai keunggulan bersaing berkelanjutan (Studi kasus Pda UMKM Batik Di pekalongan (Unpublished master's thesis). Universitas Diponegoro, Semarang, Indonesia.

Humas Kota Bundung. (2018). Little Bandung di Bandung menjawab. Retrieved from https://bit. ly/2RS70XO (accessed 13 February, 2018)

Kotler, P., \& Keller., K. (2009). Marketing management. New York, NY: Pearson Educational International.

Nejad, E. B., \& Poorsabzevari, R. A. (2016). A new method of winner determination for economic resource allocation in cloud computing systems. Journal of Advances in Technology and Engineering Research, 2(2), 12-17. doi:https://doi.org/ 10.20474/-jater2.1.3

Porter, M. E. (1990). The competitive advantage of nations. Competitive Intelligence Review, 1(1), 14-14. doi:https://doi.org/ 10.1007/978-1-349-11336-1_2

Putri, Y. R. (2015). Transformational leadership and its impact to lecturers intellectual capital factors in Telkom economics and business school Telkom University. International Journal of Business and Administrative Studies, 1(1), 35-41. doi: https://doi.org/10.20469/ijbas.10006

Rudito, P., \& Sinaga, M. F. N. (2017). Digital mastery. Jakarta, Indonesia: Gramedia.

Saputri, . M. H. D., M. E. (2016). Blue ocean strategy for creating value innovation: A study over kedai digital in Yogyakarta, Indonesia. Journal of Administrative and Business Studies, 1(1), 14-20. doi:https://doi.org/10.20474/jabs-1.1.3

Selvina, M. (2016). Indonesian accountant vs foreign accountant in indonesian job competition as an effect of Asean economic community 2015. International Journal of Business and Administrative Studies, 2(1), 16-19. doi:https://doi.org/ 10.20469/ijbas.2.10004-1

Syahmardi, Y., \& Ade, O. M. (2016). Pemanfaatan sosial commerce terhadap keunggulan bersaing dan implikasinya bagi kinerja bisnis umkm di provinsi jambi (Unpublsihed master's thesis). Jambi University, Jambi University.

Tiago, M. T. P. M. B., \& Veríssimo, J. M. C. (2014). Digital marketing and social media: Why bother? Business Horizons, 57(6), 703-708. doi:https://doi.org/10.1016/j.bushor.2014.07.002

Tim Deloitte. (2015). Deloitte access economics. Retrieved from https://bit.ly/2AIIOU8 (accessed 15 February, 2018)

Wardhana, A. (2016). Strategi digital marketing dan implikasinya pada keunggulan bersaing ukm di indonesia (Unpublished master's thesis). Universitas Telkom, West Java, Indonesia.

Yoo, J., Lee, M. K., \& Lee, W. S. (2016). Asymmetrical corporate responses to economic information: Applying the firm size effect. Journal of Administrative and Business Studies, 2(1), 29-34. doi:https://doi.org/10.20474/jabs-2.1.4 